\title{
THE INCIDENCE FOUND AT NECROPSY OF METASTASES TO THE STERNUM AND ILIAC CREST, WITH SPECIAL REFERENCE TO CARCINOMA OF THE LUNG
}

\author{
BY \\ M. O. SKELTON \\ From Lewisham Group Laboratory, London
}

(RECEIVED FOR PUBlication JUNE 26, 1958)

Marrow samples from patients under investigation for anaemia only occasionally reveal metastatic malignant cells. Berkheiser (1955) detected malignant cells in 12 of 246 routine marrow aspirations from 241 patients, in most of whom the investigation was being done for the diagnosis of various types of anaemia. His series included six cases of multiple myeloma, a condition excluded from consideration in the investigation described in this paper. Berkheiser's other cases consisted of three of carcinoma of prostate, and one each of carcinoma of stomach, colon, and lung. Weisberger and Heinle (1949) sought for metastatic cells in the sternal marrow of patients known to have carcinoma and found them in seven, distributed as follows: two from 10 cases of carcinoma of breast, two from eight of carcinoma of lung, two from four of carcinoma of kidney, and one of five of carcinoma of prostate.

When malignant cells are found in routine diagnostic marrow smears it raises the question of the site of the primary growth.

It would be of value in approaching this problem to have some information as to the probability of particular malignant tumours metastasizing to those sites from which marrow biopsies are usually taken, namely, the sternum and iliac crest. While recognizing the shortcomings of necropsy statistics it was decided to search for metastatic malignant cells in the sternum in a series of necropsies on cases of malignant disease. Later in the investigation the iliac crest was sectioned also. It was hoped to obtain some data regarding the overall frequency of metastases to these sites in fatal cases of malignant disease, and during the investigation certain facts relating to carcinoma of the lung emerged which appeared to justify their particular consideration.

\section{Material and Methods}

The material was obtained from 225 unselected necropsies on cases of malignant neoplasm performed at Lewisham Hospital between 1954 and 1958. In three instances in this series double primary tumours were considered to be present. Malignant neoplastic conditions of the reticulo-endothelial system, myeloma, leukoses, and malignant tumours of the central nervous system were excluded.

For the first 98 cases the sternum only was sectioned; for the subsequent 127 cases both sternum and iliac crest were examined.

A thin slice from the midline of the manubrium sterni and a similar thin slice from the anterior $4 \mathrm{~cm}$. of the anterior iliac crest were decalcified, embedded in paraffin, sectioned, and stained with haematoxylin and eosin. By this histological method malignant cells are usually easy to identify by their tendency to occur in small clumps, usually demarcated from the surrounding marrow tissue, and sometimes with considerable associated stroma reaction. The degree of invasion varied from an occasional small group of cells to total replacement of marrow by neoplastic tissue.

\section{Results}

In 98 cases in which the sternum only was sectioned, malignant cells were found in 23 . Of 127 cases in which both sternum and iliac crest were examined, malignant cells were found in 22: in both in 15 cases, in the sternum only in five cases, and in the iliac crest only in two cases (one case of carcinoma of stomach and one case of carcinoma of kidney). The overall picture is that, of 225 necropsies of cases of malignant disease, metastatic malignant cells were found in sternum or iliac crest, or both, on 45 occasions, an incidence of $20 \%$. In all these instances metastases were found to be present in other sites as well ; in five the skeleton was the only site of metastasis, in two cases of carcinoma of prostate, two of breast, and one of lung. 
TABLE I

SITE OF PRIMARY TUMOUR IN 225 CASES

\begin{tabular}{|c|c|c|c|c|c|c|c|}
\hline \multicolumn{5}{|c|}{ Site of Primary Tumour } & $\begin{array}{l}\text { No. } \\
\text { of } \\
\text { Cases }\end{array}$ & $\begin{array}{c}\text { Sternal } \\
\text { Metastases } \\
\text { in 225 } \\
\text { Examina- } \\
\text { tions }\end{array}$ & $\begin{array}{c}\text { Iliac Crest } \\
\text { Metastases } \\
\text { in } 127 \\
\text { Supple- } \\
\text { mentary } \\
\text { Examina- } \\
\text { tions }\end{array}$ \\
\hline \multirow{3}{*}{\multicolumn{2}{|c|}{$\begin{array}{l}\text { Lung } \quad \ldots \\
\text { Stomach } \\
\text { Colon and caecum }\end{array}$}} & & . & $\ldots$ & 69 & 24 & 7 \\
\hline & & . & . & $\ldots$ & 37 & 4 & 2 \\
\hline & & . & . & $\ldots$ & 21 & 2 & 1 \\
\hline \multirow{2}{*}{$\begin{array}{l}\text { Breast ... } \\
\text { Kidney }\end{array}$} & .. & . & . & . & 17 & 5 & 2 \\
\hline & . & . & . & . & 11 & 4 & 2 \\
\hline Prostate & & . & . & . & 9 & 2 & 2 \\
\hline Rectum & . & . & . & . & 9 & - & - \\
\hline \multirow{2}{*}{$\begin{array}{l}\text { Pancreas } \\
\text { Ovary ... }\end{array}$} & & . & $\ldots$ & .. & 9 & - & - \\
\hline & & & . & $\ldots$ & 6 & - & - \\
\hline \multirow{2}{*}{\multicolumn{2}{|c|}{$\begin{array}{l}\text { Urinary bladder } \\
\text { Biliary tract }\end{array}$}} & . & . & $\ldots$ & 6 & - & - \\
\hline & & . & . & . & 6 & 2 & 1 \\
\hline \multicolumn{2}{|c|}{$\begin{array}{l}\text { Biliary tract } \\
\text { Liver (primary) }\end{array}$} & & & & 5 & - & 一 \\
\hline \multicolumn{5}{|c|}{ Uterus (carcinoma of body and of } & 5 & - & — \\
\hline \multicolumn{4}{|c|}{ Malignant melanoma of skin } & $\cdots$ & 3 & 1 & - \\
\hline \multirow{2}{*}{\multicolumn{4}{|c|}{$\begin{array}{lll}\text { Unknown } & \ldots & \ldots\end{array}$}} & .. & 3 & 1 & - \\
\hline & & & & .. & 2 & - & - \\
\hline \multicolumn{4}{|c|}{ Argentaffin carcinoma of ileum } & & 2 & - & - \\
\hline \multirow{2}{*}{\multicolumn{4}{|c|}{$\begin{array}{l}\text { Penis . . } \\
\text { Haemangiosarcoma of spleen }\end{array}$}} & . & 1 & 一 & - \\
\hline & & & & $\ldots$ & 1 & - & - \\
\hline \multicolumn{2}{|c|}{ Melanoma of eye } & & . & . & 1 & - & 一 \\
\hline & oeso & phagus & . & . & 1 & - & - \\
\hline,, & laryi & & . & . & 1 & - & - \\
\hline , , & thyr & & . & . & 1 & 一 & - \\
\hline Petron̈rit & pitui & cary & $\cdots$ & . & 1 & 一 & 一 \\
\hline Retroperit & eal sa & coma & . & . & 1 & & 一 \\
\hline
\end{tabular}

The above figures include two cases of primary carcinoma of stomach with prostate, and one of argentaffin carcinoma of ileum with stomach, no marrow metastases being present in these cases.

Table I shows the site of the primary tumour in the 225 cases which form the source of material, and the number of positive findings in the sternum and iliac crest.

Carcinoma of Lung.-The 69 cases of carcinoma of lung examined during this investigation provide the largest single category of malignant neoplasm, and, with 24 instances of metastasis in the sternum, also provide the highest percentage of positive findings in this series, namely, 34.7\%.

Certain cytological types of lung cancer appear more liable to metastasize in this way than others, as Table II indicates.

TABLE II

CYTOLOGICAL TYPES OF LUNG CANCER

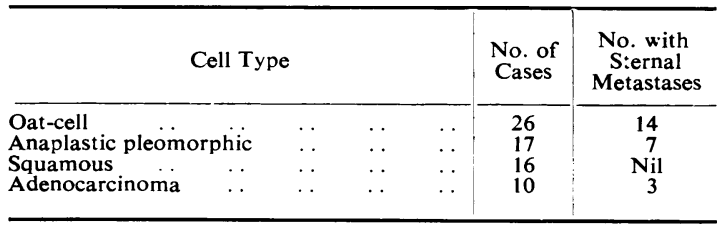

An attempt was made to grade the degree of marrow invasion according to the arbitrary scheme :

$+=$ a single metastatic deposit

$++=a$ few separate metastatic deposits

$+++=$ extensive or complete replacement of marrow by metastatic tumour cells
It was apparent that the different cell types varied in the degree of metastatic replacement they achieved (Table III).

TABLE III

DEGREE OF METASTATIC REPLACEMENT ACCORDING TO CELL TYPE

\begin{tabular}{|c|c|c|c|c|c|}
\hline \multirow{2}{*}{\multicolumn{3}{|c|}{ Cell Type }} & \multicolumn{3}{|c|}{ Dezree of Invasion of Marrow } \\
\hline & & & + & $+t$ & +++ \\
\hline $\begin{array}{l}\text { Oat-cell . } \\
\text { Anaplastic } \\
\text { Adenocarcinoma }\end{array}$ & . & $\begin{array}{l}\cdots \\
\cdots \\
\cdots\end{array}$ & $\begin{array}{l}3 \\
4 \\
1\end{array}$ & $\begin{array}{l}3 \\
2 \\
1\end{array}$ & $\begin{array}{l}8 \\
1 \\
1\end{array}$ \\
\hline
\end{tabular}

It appears that the oat-cell type of carcinoma is not only more liable to metastasize to the sternum (14 out of 26 cases - a remarkably high figure of $54 \%$ ), but also is more likely to produce extensive replacement of the sternal marrow by tumour tissue. The practical importance of such extensive replacement is that it should make it more likely that malignant cells would be obtained in a diagnostic marrow sample from such patients.

Those cases of carcinoma of the lung showing sternal metastases were arranged in three groups according to the total duration of illness from onset to death as follows (in one case the clinical history was too vague to present this) :

$$
\begin{array}{ll}
1 \text { year to } 6 \text { months } & =4 \text { cases } \\
5 \text { months to } 7 \text { weeks } & =10 \text { cases } \\
6 \text { weeks or less } & =9 \text { cases }
\end{array}
$$

Of the nine cases in which the duration was six weeks or less, in five the bone marrow was found to be almost completely replaced by malignant tissue $(+++$ grading on the above scheme).

This suggests that in suspected cases of carcinoma of the lung sternal puncture may be of value as a diagnostic procedure for the detection of malignant cells even when the clinical history is relatively short. Further, it might well be worth subjecting patients in whom thoracic surgery is contemplated to preliminary sternal puncture to try to determine whether or not skeletal metastasis has already taken place.

Miscellaneous Observations.-Apart from the cases of carcinoma of the lung, the examples of other forms of malignant disease in this series are too small to justify statistical appraisal, but it may be noted that the breast, kidney, and prostate feature as primary sites of origin for metastases to sternal and iliac marrow. This is similar to the experience of Weisberger and Heinle (1949). The discovery of metastases on five occasions in the small series of 37 cases of carcinoma of the stomach again draws attention to the tendency of this neoplasm to metastasize to bone, a fact. as 
Meyer (1957) has pointed out, not very generally appreciated. It is of interest that one case of metastasizing malignant melanoma of the skin showed extensive infiltration of the sternal marrow at necropsy. This is regarded as rare. Meyer reported one case in his series of skeletal metastases.

\section{Summary and Conclusions}

The discovery of metastatic malignant cells in bone marrow samples frequently poses the question of their origin. An attempt has been made to assess the probability of particular tumours metastasizing to those sites from which bone marrow biopsies are commonly taken.

In a series of 225 cases of fatal malignant disease, excluding primary tumours of bloodforming organs, the sternum was examined at necropsy for the presence of malignant cells. In 127 cases of the series this was supplemented by examination of the iliac crest marrow. Metastases were found in one, or other, or both sites in $20 \%$ of the cases. In only two cases were metastases found in the iliac crest but not in the sternum.

Sixty-nine cases of carcinoma of the lung were included in the series and $34 \%$ showed sternal marrow metastases. With oat-cell carcinoma of lung, $54 \%$ were found to have metastasized to the sternum. Indirect evidence is adduced suggesting that extensive sternal metastases may be present in cases of carcinoma of the lung after a relatively short clinical illness. It is suggested that sternal marrow biopsy may have a place as a diagnostic and as a screening procedure in this condition.

The tendency of carcinoma of the stomach to metastasize to the skeleton is further confirmed.

I wish to express my thanks to Mr. H. Eastwood for his technical assistance in this investigation.

\section{REFERENCES}

Berkheiser, S. W. (1955). Cancer, 8, 958.

Meyer, P. C. (1957). Brit. J. Cancer, 11, 509.

Weisberger, A. S., and Heinle, R. W. (1949). Amer. J. med. Sci., 217, 263. 